\title{
Visual Reporting in the Cooperative Group
}

\author{
Yating Guo \\ Accounting and Finance Division, University of Stirling, Scotland, United Kingdom
}

\section{Email address:}

yag00011@students.stir.ac.uk

\section{To cite this article:}

Yating Guo. Visual Reporting in the Cooperative Group. Journal of Finance and Accounting. Vol. 3, No. 6, 2015, pp. 211-214. doi: 10.11648/j.jfa.20150306.16

\begin{abstract}
This equity research based paper evaluates Co-operative Group, the Britain's largest UK mutual business. In addition, this essay will provide an indication of the visual reporting of Co-operative Group over the last decade, and provides key changes and developments in their financial statements to existing and potential investors. A significantly changes of Cooperative Group visual reporting comes from their financial information, hence, Co-operative Group's prospect will be heavily affected by colour, graph, photographs and illustration. This paper, therefore, will pay attention to various aspects to analyse, use the full set of financial statements for the year (the document which includes the full statement of financial performance, statement of financial position, cashflow and notes), rather than summary accounts. In the literature review part, visual aids will be taken into account due to its significant impacts on company development of visual representations. Based on all analysis of the visual reporting, therefore, it is a way of turning formal documents into a public relations document.
\end{abstract}

Keywords: Visual Reporting, Financial Reporting, Co-operative Group, Visual Aids

\section{Introduction}

At present, visual reporting and data visualization has become increasingly essential elements of financial reporting. The purpose of this report is to analysis visual aids of the annual report and accounts of the Co-operative Group, which is the Britain's largest UK mutual business. The Cooperative Group is an extraordinary family of businesses, including food, travel, pharmacy, banking, insurance, funeral-care, legal services and electrical. In addition, this report is based on last ten years (from 2004 to 2013) financial information of the Co-operative Group. It is a best way for the public to get a clear perspective of what the changes of annual report and carry out an evaluation of the results, especially for investors.

In the main body part, firstly, this essay will provide a general overview of the Co-operative Group and explain why we choose it. Then, this essay is going to evaluate some significance changes and conditions through past 10 year's annual report. After that, these papers will summary some key points which we have identified from academic literature. A brief conclusion on the discussion and evaluation of above sectors will be illustrated at last.

\section{Background}

The Co-operative Group is a retail business company based in Great Britain. More than 165 years has passed since the group is established in 1844 . At that time, the company was "the Co-operative Wholesale Society". The group is one of the largest companies of its company style, over 10,000 employees and the group's headquarter is in Manchester. The group's business is mostly based in UK, about 85 percent and has a wide range of business, including the Co-operative Food, bank service, legal service, travel agency etc. The Cooperative Group is well known in its food service. The food service has over thirty thousand stores in UK and it is usually called by people as "the Co-op". The wide range of business of the group is well evaluated by the customers. According to the customer satisfaction investigation in 2013, the result of the customer satisfaction in pharmacy and funeral care services is $91.7 \%$ and $98.5 \%$.

The most special part of this group is that over seven million members of the group own the company and all of them have the right of participate in the company decision. Everyone who is over 16 can be a member of the family and at the end of every year, all the members will receive a profit which is based on the member's share and the net income the group has made during this year. For example, the group paid 
70.4 and 51.4 million pounds to its individual members respectively in the year 2011 and 2012. The difference between the Co-operative Group and other customer cooperatives is that the membership is both opened to individuals and independent society members.

There are some reasons for us to choose the Co-operative Group. First of all, a lot of company information can be found on the Internet. For example, we can find 10 years of annual reports on the company website. These ten years documents give a specific direction on how this group develops its business and how to focus on their target customers. All these indicators may reflect the skills of visual reporting used each year. For instance, after the year 2010, there is a rapid increase in sales volume and the number of pictures used doubled as well. Secondly, there is lots of business in the co-operative group, food service, legal service, bank etc. as the industry closely relating to daily life, it is a short cut for research group to scan for its insight strategy movements and it may coordinate its behavior for financial window dressing. In this case, a wide range of business can reduce the company risk. Next, the company's annual reports changed a lot during the past 10 years. Each part of the annual reports also have significant differences compared with the past years. That is a main reason for research group to choose firm.

\section{Literature Review}

Companies use annual reports as a means of advertising and public relations communications (Beattie and Jones 2008). There is an increased and accelerated trend for companies using visual reporting in corporate reports (Davison, 2007). Visuals can communicate feelings, attitudes and needs that are difficult to articulate, identify intangible dimensions that are difficult to conceive and express, stimulate a more metaphoric what of thinking, inspire the imagination, and assist creativity and interaction in group discussions (Morgan, 1999). Visual appearance stimulus mind responds, and it uses the responds to get some initial judgment that in a given context or environment, what the brand represents or what the brand stands for (Richard Slack, 1999). Visuals have the potential to strike a more implicit way of seeing and thinking, they also offer an absence from words, visuals can deliver complex messages, which are usually difficult to express with verb (Morgan, 1999). Courtis (2004) said companies used more colors when profitability changes.

Colors are concerned with favourable perception formation and investment allocations. Properly use of color can depict predetermined impressions about enterprise's financial health and future. There was a significant promote in human representation with the style of the human face since last several years. (Campbell et al, 2009).

After 2004, operating review, operating and financial review and remuneration report are the most popular sections which included in financial reports. Since the year 1989, there is an increasing tendency of graphs. As the two measurements for evaluating its performance whether good or not, the one is the changing trend in EPS (earnings per share), which is specifically presenting for current year; the other alternative is the variable movements displaying in graphs, which aims at the signal changes for the current moment (Beattie et al, 2008).

Pictures are regarded by accountants as lightweight elements of financial statements traditionally (Davison, 2006). In chairman's statement, operating review, chief executive's statement, financial review, corporate social responsibility sections, pictures were widely used. (Beattie et al, 2008).

Graphs can attract our attention, it is special that if their visual is outstanding increased by the use of color; the reason is graphs rely on spatial, rather than language, we can use our predominant visual sense to see the information in a direct way and immediately; the information can be readily revitalized; in the fixed context of corporation's annual reports, graphs provide oases of color and interesting that active the presentation of data and information (Beattie et al, 2002). The presentational format of graph leaves the judgments of performance and environmental variables (Beattie et al, 1997). Graphs are used to analysis data, and to present or communicate information to audiences (Uyar, 2009).

Graphs have increased usage among years in annual reports. In 1990s, over 80\% of companies in Australia, U.S. and U.K. use graphs in annual reports. Managers, which used graphs as 'impression management', use photographs to influence information acquisition and evaluation behaviours. This kind of presentational format affects human viewpoint and judgements to this company (Beattie et al,1997).

Beattie et al wrote a journal in 2008 demonstrated that using graphs can enhance the potential to communicate and attract reader's attention. Graphs are eye-catching and memorable which retain better representation than numerical or textual information. It also helps explaining financial performance as $40 \%$ of stockholders spend 5 minutes or less on annual report in Squier's report. In most circumstance, graphs are included in annual reports with favourable rather than unfavourable performance. Graphs can give a more favourable view of performance by extending the axes' scales. All these favourable financial performance in annual reports will disturb readers and create a scene of a welloperated company which is not (Beattie et al, 1999).

\section{Visual Analysis}

\subsection{Colour}

According to analysis of previous paragraph, we can through the literatures found out the importance of colors and structure for annual reports. This paragraph will pay more attention on how the colours apply in real annual reports. According annual reports of co-operative company from 2004 to 2012, it can be seen that colours affect annual reports. In 2004, referring to words of chairman Co-operative Group had an unsatisfactory financial result; the performance of Co-operative Group was attacked by difficult year for both CIS and food retail, therefore the red and purple colours were used whole annual report. Financial department would like to 
send a signal to shareholders or other investors when the company in an undesirability situation. However, from another aspect, the red and purple colors can encourage managers and employees to work hard next year. Actually, this point also reflects in the annual reports. In annual reports 2004, Co-operative Group made many strategies for next year and adjust the poor performance of this year.

In contrast with 2004, 2005 was a profitable year. According to the annual report, it described the company has changed the way in many section's operating activities, such as improving customer service and reducing cost, these were the reasons that 2005 's profit looks better than last year. Under this situation the financial department of company chose lake green as annual report's colors. Green represents hopes and new hence financial department would like to use this color to tell shareholders that company had a good situation and earned more profit during this year. After survival, Co-operative Group had a period of rise. This also showed in the annual report of 2006, the chairman used "revival" to describe the performance of company. Thus, orange represents passion and energy among whole 2006 annual report. It also sent a signal to investors that they can invest more money in company. Meanwhile it can attract more investment from other potential investor though annual report.

From 2007 to 2009, the financial department of Cooperative Group choose light grey, light green and light blonde for annual report, those colors can give shareholder a peaceful feeling. On the other hand it also reflected managers want shareholder paying more attention on financial statement, due to a balanced development of this period, the Co-operative Company kept a stable development. Cooperative Company published bonds between 2010 and 2012, therefore for this three years the annual report become more and more professional and office blue as main colors for annual reports. Office blue can show the normalization to outsiders that can give more confidences to investors.

\subsection{Graph Analysis}

After the year 2000, graph became the trend to replace the use of key financial performance, which was reached $98 \%$ in calculation that almost all the company would employ graph in their Annual Report. With its features, it drives a tool to analyse and suggests a need for information disclosure and stakeholders. In Co-operative Group, the entire conditions of using graphs divided into 3 periods (which is relying on 10 years annual report), that is, basic period from 2004 to 2006 , improved period 2007 to 2009, and professional period 2010 to 2012. And relying on differences in each period, graphs are being used for different functions.

In the basic period, from the year 2004 to 2006, graphs are more like a tool to convey basic information, like business scales, bar chart for profits and pie chart for market shares. Preston et al, (1996) claimed that the annual report is designed for conveying messages for different purposes in recent years. What's more, as published evidence to indicate financial information in flexible way, it aims at stakeholders from executive management to auditors. In the year 2004, there are more than 110 pictures, but almost of them $76 \%$ (78 out of 110 pieces) are financial tables or statements. As Campbell et al. announced in the year 2006 as well, "an average of 37 pages in 1974 to 90 pages in 2000 to the visual page has increased continuously". In the year 2006 of Cooperative Group's, there are 147 pieces of pictures used in 136 pages of the annual report.

In improved period, arrangement seems more logical. Accounting description of visual reporting has been divided into two types, assumption-based structure and storytelling structure. It has concluded that the storytelling structure is more convenient for the case of (Beattie, 2008). For example, in the year 2009, the annual report of Co-operative has jumped to 98 in total. It has been applied to background, slogan, business scale, face work, footnote and eye-catching. To some extent, description levels may fade-off the depth of the words, but numerous images and its impressive effects almost paid back all the possibilities. In this case, this period of the annual report could give the audience a general view of financial performance and make people contract with that, but seriously, it is kind of dull and boring. The significant and growing presence of pictures in annual accounts, having described by Levinas and Bauman (2002), which summarised the needs to make the connection between graph and narrative. In other words, it is necessary to conclude the nature of the phenomenological encounter with the required determination in orders. In the professional period of Co-operative's, the main task is to make graphs like the words naturally.

\subsection{Photographs and Illustration}

Seeing from the annual report, the structure and layout of Co-operative Group have gone through big changes. The front page part has changed in a proper way. The focus has changed from the normal word 'annual report' to employees and customers in shops. It can leave readers an approachable feeling about this company. Moreover, since 2005, ascending pictures about customers and employees are included annual report rather than just managers of the Co-operative Group. It can show the purpose of annual report is not only for professionals but normal people as well.

In 2004 and 2005's annual report, all people included are whole-length portraits. From then on, the pictures about people are all only with a smiling face. With this change, it gives a more appropriate and approachable way to readers than before.

For Co-ops, there is a sign that it will use small amount of pictures in not good performing years. For example, in the year 2008, there is only $34 \%$ of income and expense compared with last year whilst the amount of pictures usage reduced sharply as well. And these pictures are all right-sided columns structured, for this setting; the annual report may look neat and tidy.

In May 2011, the company made a publication of Offering Circular. That is why the annual report in 2010 is more designable and eye-catching than before. This could attract investors and potential investors to buy their bonds. From 2011 's annual report, the annual report starts stating the risks 
of the industry may occur and lists the mitigations as well. In addition to that, the individually performance of each segment may also give information for annual report as well. By giving this kind of information, people who bought their bonds will have faith in this company and potential buyers can also be attracted. The side tabs are in use from this year as well; these can help readers getting to each part quickly (especially for those people only focus on specific part).

\section{Conclusion}

In conclusion, this paper has introduced the key changes and developments in the Co-operative Group's visual reporting. Visual aids such as graphs, colour and photographs are extensively use by companies to communicate financial information. According to these three sections this paper discussed above, it is easy to find out that the visual reporting of the Co-operative Group is constantly changing and become integrity. In the colour section, economic situation and operating performance was reflected by colour and font format. Furthermore, with the change of the annual reports of colour; it always represents the valuation of company accurately from the financial department. To some extent, it can influence potential investors and shareholders as well. In the graph part, the function of graph has been developed from simple tool to display KPI (Key Performance Indicator), then step to a powerful media in demonstration of logical performance and closely connect to customers. In the photographs and illustration section, the company mainly concentrates on the employees and customers welfare this decade rather than only focus upon central managers and investors.

Above our research, apparently, visual reporting has a profound influence upon the financial reporting.

\section{References}

[1] Beattie, V., Dhanani, A., and Jones, M. (2008), Investigating presentational change in UK annual reports: a longitudinal perspective. Journal of Business Communication, 45 (2). pp. 181-222.

[2] Beattie, V., and Jones, M.J. (1992) The use and abuse of graphs in annual reports: a theoretical framework and an empirical study. Accounting and Business Research, 22 (88). pp. 291-303.

[3] Beattie, V., and Jones, M.J. (1997) A comparative study of the use of financial graphs in the corporate annual reports of major u.s. and u.k. companies. Journal of International Financial Management and Accounting, 8 (1). pp. 33-68.

[4] Beattie, V., and Jones, M.J. (1999) Australian financial graphs: An empirical study. Abacus, 35 (1). pp. 46-76.

[5] Beattie, V., and Jones, M.J. (2004) Measurement distortion of graphs in corporate reports: an experimental study. Accounting, Auditing and Accountability Journal, 15 (4). pp. 546-564.

[6] Beattie, V., and Jones, M. (2008) Corporate reporting using graphs: a review and synthesis. Journal of Accounting Literature, 27 . pp. 71-110.

[7] Campbell, D.J., Moore, G. and Shrives, P.J. (2006), "Crosssectional effects in community disclosure", Accounting, Auditing \& Accountability Journal, Vol. 19 No. 1, pp. 96-114.

[8] Campbell, D, McPhail, K and Slack, R (2009) Face work in annual reports, informed by Levinas and Bauman (2002), Accounting, Auditing and Accountability Journal, 22, 6, 907932.

[9] Co-operative Group Plc (2004) Annual report [Online]. Available at: www.cooperative.coop/Corporate/PDFs/Annual\%20Report\%202004.p df (Accessed: 14 February 2014).

[10] Co-operative Group Plc (2005) Annual report [Online]. Available at: www.cooperative.coop/Corporate/PDFs/Annual_Report_2005.pdf (Accessed: 14 February 2014).

[11] Co-operative Group Plc (2006) Annual report [Online]. Available at: www.cooperative.coop/Corporate/PDFs/AnnualReport2006.pdf (Accessed: 14 February 2014).

[12] Co-operative Group Plc (2007) Annual report [Online]. Available at: www.cooperative.coop/Corporate/PDFs/Annual_Report_2007.pdf (Accessed: 14 February 2014).

[13] Co-operative Group Plc (2008) Annual report [Online]. Available at: www.cooperative.coop/Corporate/PDFs/Annual_Report_2008.pdf (Accessed: 14 February 2014).

[14] Co-operative Group Plc (2009) Annual report [Online]. Available at: www.cooperative.coop/Corporate/PDFs/Annual_Report_2009.pdf (Accessed: 14 February 2014).

[15] Co-operative Group Plc (2010) Annual report [Online]. Available at: www.cooperative.coop/Corporate/PDFs/Annual_Report_2010.pdf (Accessed: 14 February 2014).

[16] Co-operative Group Plc (2011) Annual report [Online]. Available at: www.cooperative.coop/Corporate/PDFs/AnnualReport/Annual_Report_2011.pdf (Accessed: 14 February 2014).

[17] Co-operative Group Plc (2012) Annual report [Online]. Available at: www.cooperative.coop/Corporate/PDFs/Annual-

Report/2012/TCG_Annual-Report-2012.pdf (Accessed: 14 February 2014).

[18] Courtis, J (2004) Colour as visual rhetoric in financial reporting, Accounting Forum, 28, 3, 265-281.

[19] McKinstry S., Designing the annual reports of Burton plc from 1930 to 1994.Accounting, Organizations and Society, Jan 1996 Volume: 21 Issue: 1.

[20] Preston, A. M., Wright, C., \& Young, J. J. (1996), Imaging annual reports. Accounting, Organizations and Society, 21(1), 113-137. 